\title{
ANALISIS BREAK EVEN POINT (BEP) SEBAGAI INSTRUMEN DALAM PERENCANAAN LABA PADA PDAM TIRTA KAHURIPAN KABUPATEN BOGOR
}

\author{
Hedar Rusman \\ Dosen STIE Bisnis Indonesia, Jakarta
}

\begin{abstract}
Expense that happened at entitas can be dissociated pursuant to fixed cost and variable cost. Dissociation is expense of semivariabel according to fixed cost and variable cost doneby using square least method. PDAM Tirta Kahuripan Bogor not yet grouped costs into variable cost and fixed cost. Company only grouping in direct cost, indirect cost, and other expense for financial report. For applying analyse BEP hence the costs divided to become fixed cost and variable cost. Total cost remain to for the year of 2015 is Rp.68.439.613.600,- and Rp.38.478.853.246 for variable total cost. By using square least method forecast sale of company for year 2016 equal to Rp. 128.993.087.500,-. Result of obtained calculation indicate that PDAM Tirta Kahuripan Bogor have reached break even point, sale of company for the year of 2015 equal to Rp.114.233.723.238,- have is abysmal of break even point. Pursuant to dot analysis settl with to be obtained that level of PDAM Tirta Kahuripan Bogor profit from sales revenue irrigate for the year 2015 is Rp. 731.118.287,232,-. By using square least method for the forecasting of sale, forecasting of sale company in the year 2016 is Rp. 128.993.087.500,-, percentage of make-up of sales revenue for the year of 2016 is 12,92\%. Because proporsional with increase of variable cost, hence level of variable cost is Rp. 43.450.321.085. Pursuant to calculation of BEP, Contribution Margin Ratio, and Margin Safety of obtained by PDAM Tirta Kahuripan Bobor debet-record account from sale irrigate in the year 2016 is Rp. 17.103.193.472,-
\end{abstract}

Keyword: Break even point, profit planning.

Abstrak: Biaya yang terjadi pada perusahaan dapat dipisahkan berdasarkan biaya tetap dan biaya variabel. Pemisahan biaya semivariabel menurut biaya tetap dan biaya variabel dilakukan dengan menggunakan metode least square. PDAM Tirta Kahuripan Kabupaten Bogor belum mengelompokkan biaya-biaya kedalam biaya variabel dan biaya tetap. Perusahaan hanya mengelompokkan dalam biaya langsung usaha, biaya tidak langsung, dan biaya di luar usaha untuk keperluan penyusunan laporan laba/rugi perusahaan. Untuk keperluan penerapan analisis BEP maka biaya-biaya tersebut dibagi menjadi biaya tetap dan biaya variabel. Total biaya tetap untuk 2011adalah sebesar Rp.68.439.613.600,- dan total biaya variabel Rp.38.478.853.246,-. Selama lima tahun terakhir, penjualan perusahaan meningkat setiap tahunnya. Dengan menggunakan metode least square penulis meramalkan penjualan perusahaan 2016 sebesar Rp. 128.993.087.500,-. Hasil perhitungan yang diperoleh menunjukkan bahwa PDAM Tirta Kahuripan Kabupaten Bogor telah mencapai tingkat break event point (titik impas) bahkan tingkat penjualan perusahaan untuk 2015 sebesar Rp.114.233.723.238,- telah melampaui tingkat break event point (BEP) yaitu Rp.103.202.264.310,-. Berdasarkan analisis titik impas diperoleh bahwa besarnya laba PDAM Tirta Kahuripan Kabupaten Bogordari hasil penjualan air untuk 
2015 adalah sebesar Rp. 731.118.287,232,-- Dengan menggunakan metode least square untuk peramalan penjualan, diperoleh peramalan penjualan perusahaan pada 2016 adalah sebesar Rp. 128.993.087.500,-, persentase peningkatan hasil penjualan untuk 2016 adalah 12,92\%. Karena proporsional dengan kenaikan biaya variabel, maka besarnya biaya variabel adalah Rp. 43.450.321.085. Berdasarkan perhitungan BEP, Contribution Margin Ratio, dan Margin of Safety diperoleh perkiraan laba PDAM Tirta Kahuripan Kabupaten Bobor dari penjualan air pada 2016adalah Rp. 17.103.193.472,-

Kata kunci: Break even point, perencanaan laba.

\section{PENDAHULUAN}

Dengan adanya persaingan yang semakin ketat, keunggulan berusaha diraih oleh setiap perusahaan, dan keunggulan tersebut tidak bisa berlanjut. Dan tujuan perusahaan untuk mencapai laba yang optimal memerlukan suatu perencanaan yang baik dan matang.Dengan demikian ini menjadi tugas dari manajemen untuk menyusun perencanaan-perencanaan yang penting bagi perusahaan. Salah satu perencanaan penting dalam perusahaan adalah perencanaan laba. Perencanaan laba diperlukan sebagai perencanaan operasi atau penganggaran terhadap pendapatan penjulan dan beban operasi dalam mencapai sasaran laba tertentu. Instrumen analisis perencanaan laba antara lain:

1. Analisis titik impas / pulang pokok (Break Even Point Analysis)

2. Leverage operasi (yaitu kepekaan laba operasi terhadap perubahan volume kegiatan operasi)

3. Peramalan dan penganggaran kas

4. Pengedalian divisi pada perusahaan yang didesentratralisasi

5. Model perencanaan menyeluruh

Perusahaan Daerah Air Minum (PDAM) Tirta Kahuripan merupakan badan usaha milik daerah kabupaten Bogor yang memiliki kegiatan mengelola air minum secara lengkap sehingga siap untuk dikonsumsi oleh masayarakat Bogor dan Depok. Dalam hal perencanaan laba PDAM Tirta Kahuripan mungkin sudah menggunakan salah satu dari analisis yang ada tersebut sehingga perusahaan menentukan kebijaksanaan bahwa setiap tahun laba harus naik dan pelayanan pada pelanggan meningkat. Pada penelitian ini penulis mencoba menggunakan analisis BEP sebagai instrumen dalam perencanaan laba perusahaan. Berdasarkan uraian di atas maka penulis memberikan judul penelitian ini “Analisis Break Even Point (BEP) Sebagai Instrumen Dalam Perencanaan Laba Pada PDAM Tirta Kahuripan Kabupaten Bogor”.

\subsection{TINJAUAN TEORI}

\subsubsection{Pengertian Laba}

Laba atau profit didefinisikan sebagai surplus atau kelebihan pendapatan dari penjualan atas seluruh biaya. Dimana pendapatan penjualan meliputi seluruh pendapatan yang diperoleh perusahaan dalam kegiatan usahanya dan biaya secara keseluruhan meliputi seluruh biaya yang harus dikeluarkan oleh perusahaan dalam kegiatan usahanya tersebut. Berdasarkan definisi di atas, maka laba dapat diuraikan secara matematis sebagai berikut menurut Milton F. Usry et. al $(1992,203)$ adalah Laba = Pendapatan total $-($ Biaya Variabel Total + Biaya Tetap Total) yang artinya sama saja dengan : Pendapatan

Total $=$ Biaya Tetap Total + Biaya Variabel Total + Laba

$\mathrm{R}=\mathrm{F}+(\mathrm{V} \times \mathrm{R})+\pi$

$\mathrm{R} \quad=\mathrm{P} \times \mathrm{Q}$ 
$\mathrm{P} \times \mathrm{Q}=\mathrm{F}+(\mathrm{C} \times \mathrm{Q})+\pi$

Keterangan :

$\pi=$ laba atau profit

$\mathrm{R}$ = hasil penjualan total

$\mathrm{F}$ = biaya tetap total

$\mathrm{V}=$ biaya variabel untuk setiap dollar/rupiah hasil penjualan

$\mathrm{P}=$ harga jual per unit

$\mathrm{Q}=$ kuantitas produk yang terjual

$\mathrm{C}=$ biaya variabel per unit

\subsubsection{Perencanaan Laba}

Salah satu perencanaan yang sangat penting yang harus disusun oleh perusahaan adalah perencanaan laba. Perencanaan laba perlu dilakukan karena banyak faktor-faktor yang tidak bisa dipastikan di masa datang. Dengan demikian perusahaan perlu menyusun perencanaan untuk mengantisipasi masa datang.Perencanaan laba merupakan suatu bentuk perencanaan operasi atau penganggaran yang dilakukan terhada pendapatan penjualan dan beban operasi dalam mencapai sasaran laba tertentu. Dalam menetapkan sasaran laba tertentu, pihak manajemen harus mempertimbangkan faktor-faktor menurut (Milton F. Usry 1992:4) :

a. Laba atau rugi yang dialami dari volume penjualan tertentu.

b. Volume penjualan yang harus dicapai untuk menutup seluruh biaya yang terpakai, untuk menghasilkan laba yang memadai agar dapat membayar deviden bagi saham preferen dan saham biasa, dan untuk menahan sisa laba yang cukup lama memenuhi kebutuhan perusahaan di masa depan.

c. Titik impas/pulang pokok (break even point)

d. Volume penjualan yang dapat dihasilkan oleh kapasitas operasi pada saat ini.

e. Kapasitas operasi yang diperlukan untuk mencapai sasaran laba.

f. Hasil pengembalian (return) atas modal yang digunakan.

Sedangkan keterbatasan dari perencanaan laba menurut (Milton F. Usry 1992, 7) adalah:

a. Peramalan atau pemrakiraan bukanlah ilmu pasti, dalam setiap penyusunan anggaran akan terdapat sejumlah pertimbangan tertentu.

b. Anggaran dapat mengikat perhatian manajer pada sasaran tertentu yang tidak selaras dengan tujuan organisasi secara keseluruhan.

c. Perencanaan laba memerlukan kerjasama dan peran serta dari seluruh anggota manajemen.

d. Sistem penganggaran akan menghambat apabila hal itu memotivasi seseorang untuk mengambil tindakan yang tidak memberikan hasil terbaik bagi organisasi.

e. Perencanaan laba tidaklah menghapus maupun mengambil alih peranan bagian administrasi.

f. Pelaksanaan rencana memerlukan waktu. Manajemen sering kali cepat jengkel dan putus asa karena mengharapkan terlalu banyak dalam tempo yang terlalu singkat.

Suatu perusahaan yang telah melakukan perencanaan laba adalah perusahaan yang telah mempunyai data-data yang lengkap dari kegiatan perusahaan dan ditunjang oleh manajemen yang baik. Karena setiap bagian harus saling menunjang untuk terlaksananya dari perencanaan laba tersebut. Baik itu bagian produksi, keuangan maupun pemasaran. 


\subsubsection{Definisi Titik Impas (Break Even Point)}

Analisis titik impas merupakan suatu alat yang penting di dalam mengadakan perencanaan dan pengawasan dalam bidang keuangan perusahaan. Untuk lebih jelasnya, berikut ini akan diberikan definisi dari titik impas menurut pendapat yang dikemukakan oleh beberapa para ahli: Menurut Riyanto (1994 : 279): "Volume penjualan dimana penghasilannya tepat sama besarnya dengan biaya totalnya, sehingga perusahaan tidak mendapatkan keuntungan atau menderita kerugian dinamakan Break Event Point”. Sedangkan menurut Syafruddin Alwi (1994:265):

"Break Even Point dapat diartikan sebagai suatu titik atau keadaan dimana perusahaan didalam operasinya tidak memperoleh keuntungan dan tidak menderita kerugian. Dengan kata lain, pada keadaan itu keuntungan dan kerugian sama dengan nol.” Menurut Mulyadi (1992:72): "Suatu keadaan dimana suatu usaha tidak memperoleh laba dan tidak menderita rugi. Dengan kata lain, suatu usaha dikatakan impas apabila jumlah penghasilan sama dengan jumlah biaya, atau apabila marginal income (contribution margin) hanya dapat digunakan untuk menutup biaya tetap saja." Dan menurut Riyanto (1994:72) adalah:“Analisis Break-even adalah suatu tehnik analisis untuk mempelajari hubungan antara biaya tetap, biaya variabel, keuntungan dan volume kegiatan. Apabila suatu perusahaan hanya mempunyai biaya variabel sama maka tidak akan muncul masalah break-even dalam perusahaan tersebut. Masalah break-even baru muncul apabila suatu perusahaan disamping mempunyai biaya variabel juga mempunyai biaya tetap. Besarnya biaya variabel secara totalitas tidak akan mengalami perubahan meskipun ada perubahan volume produksi.” Dari definisi para ahli dari berbagai cabang ilmu di atas, maka Titik Impas adalah suatu kegiatan dimana pendapatan yang diterima perusahaan dari penjualan sama dengan total biaya yang telah dikeluarkan untuk kegiatan tersebut dan pada tingkat ini perusahaan tidak mengalami keuntungan atau pun kerugian, dengan kata lain labanya sama dengan nol. Dengan demikian dapat ditarik kesimpulan bahwa analisis titik impas tidak hanya dapat digunakan untuk mengetahui keadaan perusahaan tetapi juga dapat memberikan informasi kepada manajemen perusahaan mengenai berbagai tingkat volume penjualan serta hubungan dengan kemungkinan memperoleh laba menurut tingkat penjualannya.

\subsubsection{Pengertian dan Penggolongan Biaya dalam Analisis Titik Impas}

\subsubsection{Pengertian Biaya}

Didalam melakukan kegiatan penjualan, perusahaan harus memperhitungkan biaya-biaya yang akan dikeluarkan untuk kegiatan tersebut supaya dapat ditetapkan suatu tingkat harga yang tepat. Tingkat harga tidak bisa ditetapkan dibawah biaya produksi karena hal ini dapat menyebabkan perusahaan mengalami kebangkrutan. Untuk itu biaya sangat penting selain untuk menetapkan suatu tingkat harga yang tepat juga dapat menciptakan suatu harga yang dapat bersaing sehingga tidak membuat tingkat permintaan menurun. Menurut Mulyadi (1992:7) adalah: "Biaya merupakan pengorbanan sumber ekonomi, yang diukur dalam satuan mata uang, yang telah terjadi atau yang akan terjadi untuk tujuan tertentu”Menurut Horngren (1991 : 21-22) adalah: "Biaya sebagai sumber daya yang dikorbankan untuk mencapai suatu sasaran atau tujuan tertentu untuk sekarang, anggap saja biaya seperti yang diukur dengan cara akuntansi tradisional, seperti unit moneter yang harus dibayarkan atas barang atau jasa yang diperoleh.” Berdasarkan definisi para ahli diatas, maka disimpulkan bahwa biaya adalah pengorbanan ekonomis dalam bentuk uang yang telah atau akan terjadi yang digunakan untuk mencapai tujuan tertentu dimana pengorbanan ekonomis ini dilakukan untuk memperoleh barang atau jasa yang digunakan untuk mencapai penghasilan. 


\subsubsection{Penggolongan Biaya}

Karena biaya yang harus dikeluarkan di dalam pelaksanaan operasi perusahaan terdiri dari berbagai macam biaya maka biaya-biaya tersebut harus dipisahkan menurut hubungannya dengan perubahan volume kegiatan dalam perusahaan. Perusahaan ini dimaksudkan untuk mengetahui bagaimana perilaku biaya tersebut dalam hubungannya dengan perubahan volume kegiatan perusahaan tersebut. Penggolongan biaya menurut Usry et al. (1992, 318) adalah:

1. Biaya Tetap

Biaya tetap tidak akan berubah jumlahya meskipun volume kegiatan meningkat atau menurun. Namun, jumlah biaya tersebut akan tetap sama hanya dalam rentang/range kegiatan tertentu.

2. Biaya Variabel

Biaya variabel meningkat secara proporsional dengan peningkatan kegiatan dan menurun secara proporsional dengan penurunan kegiatan. Biaya variabel meliputi biaya bahan baku, pekerja langsung, bahan penolong tertentu, pekerja tidak langsung tertentu, biaya karena perkakas yang mudah rusak, biaya pengerjaan ulang, dan biaya karena kerusakan yang normal.

3. Biaya Semivariabel

Biaya semivariabel memiliki kedua sifat, baik tetap maupun variabel. Tiga pertimbangan terhadap sifat semivariabel dari beberapa biaya adalah :

a. Sekurang-kurangnya diperlukan organisasi atau perbekalan dan jasa dalam jumlah tertentu agar pabrik selalu siap sedia untuk beroperasi.

b. Penggolongan akuntansi, yang didasarkan pada obyek pengeluaran atau fungsi, lazimnya menggabungan unsur-unsur tetap dan variabel

c. Faktor-faktor produksi dapat dibagi ke dalam unit-unit yang sangat kecil.

Penentuan unsur-unsur tetap dan variabel pada beban semivariabel perlu untuk merencanakan, menganalisis, mengendalikan, mengukur, atau mengevaluasi biaya dalam berbagai tingkat kegiatan. Karena cara perhitungan pada setiap metode yang sama adalah sama untuk setiap kali maka uraian dari metode-metode di atas dikemukakan secara garis besar sebagai berikut:

1. Pendekatan Historis

Pendekatan ini menghitung biaya tetap dan biaya variabel berdasarkan angka-angka atau datadata yang teleh terjadi pada waktu yang lampau, kemudian dengan menggunakan metode-metode tertentu ditetapkan untuk menjadi dasar penentuan biaya tetap dan biaya variabel untuk periode berjalan atau yang akan datang. Jadi dengan menggunakan cara ini, angka-angka selama beberapa periode dikumpulkan dan kemudian biaya-biaya itu dapat dihitung dengan metode-metode berikut:

a. Metode Titik Tertinggi dan Terendah

Dalam metode ini diadakan perbandingan suatu biaya pada tingkat kegiatan yang paling tinggi dan rendah di masa lalu. Yaitu dengan cara dari seluruh data biaya semivariabel dipilih dua tingkat biaya yaitu biaya yang paling tinggi dan paling rendah. Begitu pula dengan kapasitas yang digunakan pada saat biaya yang paling rendah tersebut terjadi dan pada saat perusahaan mengeluarkan biaya yang paling tinggi. Untuk mengetahui biaya variabel maka diadakan perhitungan dengan menggunakan rumus: 
$\mathrm{AVC}=\frac{\mathrm{SVC}_{1}-\mathrm{SVC}_{2}}{\mathrm{C}_{1}-\mathrm{C}_{2}}$

dimana :

AVC = biaya variabel per unit

$\mathrm{SVC}_{1} \quad=$ biaya semivariabel pada titik kapasitas tertinggi

$\mathrm{SVC}_{2} \quad$ = biaya semivariabel pada titik kapasitas terendah

$\mathrm{C}_{1} \quad=$ tingkat kapasitas tertinggi

$\mathrm{C}_{2} \quad=$ tingkat kapasitas terendah

b. Metode Biaya Berjaga (Standby Cost Method)

Dengan metode ini dihitung biaya tetap yang harus dikeluarkan perusahaan seandainya perusahaan untuk sementara berhenti berproduksi, sehingga produksi untuk satu bulan tertentu sama dengan nol. Biaya tetap ini adalah biaya berjaga. Sedangkan selisih dari biaya yang dikeluarkan selama satu bulan jika perusahaan berproduksi dengan biaya berjaga merupakan biaya variabel untuk bulan yang bersangkutan.

c. Metode Kuadrat Terkecil (Least Square Method)

Dengan metode ini, unsur biaya tetap dan biaya variabel ditentukan dengan persamaan matematika sebagai berikut:

Keterangan :

$\mathrm{Y}=$ besarnya biaya semivariabel

$\mathrm{a}=$ besarnya biaya tetap

$=\Sigma \mathrm{Y}-\mathrm{b} \Sigma \mathrm{X}$

$\mathrm{b}$ = besarnya biaya variabel persatuan

$=\frac{\Sigma\left(\mathrm{X}_{\mathrm{ij}}-\mathrm{X}\right)\left(\mathrm{Y}_{\mathrm{i}}-\mathrm{Y}\right)}{\Sigma\left(\mathrm{X}_{\mathrm{i}}-\mathrm{X}\right)}$

$=$ jumlah tahun untuk analisa

= besarnya tingkat produksi

\section{Pendekatan Analistis}

Menentukan berapa biaya tetap dan biaya varaibel dengan menganalisis setiap jenis biaya kemudian dibedakan mana yang merupakan unsur variabel. Umumnya pendekatan ini dilakukan melalui kerjasama antara orang-orang teknik dan staff serta kebijakan pimpinan perusahaan dengan melibatkan berbagai faktor yaitu:
a. Pertimbangan para akuntan.
b. Pertimbangan atas hasil perhitungan biaya berdasarkan metode pendekatan historis.
c. Catatan-catatan biaya di masa lampau yang bersangkutan.

\subsubsection{Metode-metode Analisis Titik Impas}

Dalam analisis titik impas, terdapat 2 metode untuk menentukan besarnya titik impas menurut Mulyadi (1992:72) yaitu:

1. Pendekatan Matematis 
Analisis BEP ini disebut sebagai Pendekatan Matematis karena dalam penyelesaian tingkat BEP menggunakan perhitungan matematis. Laba adalah sama dengan hasil penjualan dikurangkan dengan biaya atau dapat dikatakan dalam persamaan sebagai berikut:

$\mathrm{y}=\mathrm{ax}-\mathrm{bx}-\mathrm{c}$

dimana :

$\mathrm{y}:$ laba

a : harga jual per untuk nit

$\mathrm{x}$ : jumlah unit produk yang dijual

$\mathrm{b}=$ biaya variabel per unit

c = biaya tetap

Bila suatu perusahaan berada dalam keadaan BEP, maka berarti perusahaan tersebut tidak memperoleh laba atau $(\mathrm{y}=0)$ atau dinyatakan dalam persamaannya sebagai berikut:

$0=\mathrm{ax}-\mathrm{bx}-\mathrm{c}$

$\mathrm{ax}=\mathrm{bx}+\mathrm{c}$

$\mathrm{bx}-\mathrm{bx}=\mathrm{c}$

$\mathrm{x}(\mathrm{a}-\mathrm{b})=\mathrm{c}$

$\mathrm{x}=\mathrm{c}$

$\mathrm{x}=\frac{\mathrm{c}}{(\mathrm{a}-\mathrm{b})} \ldots \ldots \ldots \ldots \ldots . . . . .$. persamaan titik BEP dalam unit

Jadi dalam persamaan tersebut dapat ditulis kembali sehingga rumusnya menjadi:

Titik BEP (dalam unit $)=\frac{\text { Biaya Tetap }}{\text { Harg a jual } / \text { unit }- \text { Biaya var iabel } / \text { unit }}$

Sedangkan nilai penjualan pada saat perusahaan berada dalam keadaan impas rumusnya dapat dinyatakan dengan jalan mengalikan rumus titik BEP dalam unit dengan harga jual per unitnya (a), sehingga rumusnya menjadi:

$$
\begin{aligned}
& a(x)=a \frac{c}{a-b} \\
& a x=\frac{c a}{a-b} \\
& a x=\frac{\frac{c a}{a}}{\frac{a}{b}-\frac{b}{a}} \\
& a x=\frac{c}{1-\frac{a}{b}}
\end{aligned}
$$

Bila persamaan BEP tersebut ditulis kembali maka rumus BEP dalam rupiah adalah sebagai berikut :

$$
\text { Titik BEP }=\frac{\text { Biaya Tetap }}{1-\frac{\text { Biaya var iabel per unit }}{\text { H arg a jual per unit }}}
$$


Bila : $\frac{\text { Tota Biaya Variabel }}{\text { Hasil Penjuala }}=\frac{\text { Biaya Variabel per unit }}{\text { Harg a Jual per unit }} 0 \frac{\text { Unit Terjual }}{\text { Unit Terjual }}$

Titik BEP

$$
=\frac{\text { Biaya Tetap }}{1-\frac{\text { Biaya Total Variabel }}{\text { Hasil Penjualan }}}
$$

Karena Contribution Margin $=$ Hasil Penjualan - Biaya Variabel, sehingga dapat dinyatakan sebagai berikut:

$\mathrm{CM}=\mathrm{ax}-\mathrm{bx}$

$\mathrm{CM}$ Ratio $=\frac{\mathrm{ax}-\mathrm{bx}}{\mathrm{ax}}$

CM Ratio $=\frac{\mathrm{ax}}{\mathrm{ax}}-\frac{\mathrm{bx}}{\mathrm{ax}}$

$\mathrm{CM}$ Ratio $=1-\frac{\mathrm{bx}}{\mathrm{ax}}$

CM Ratio $=1-\frac{\text { Biaya Variabel }}{\text { Hasil Penjualan }}$

Sehingga didapatkan :

Titik BEP (dalam rupiah) $=\frac{\text { Biaya Tetap }}{\text { Contribution M arg in Ratio }}$

Contribution Margin Ratio (CMR) memungkinkan perhitungan rugi laba tanpa perlu menghitung biaya variabel secara perunit.

\section{Laba $=($ Penjualan $\times C M R)-$ Biaya Tetap}

3. Pendekatan Grafis

Metode ini dilakukan dengan membuat suatu grafik atau gambar BEP. Didalam gambar ini akan dapat diketahui sekaligus jumlah rupiah dari hasil penjualan, kuantitas yang dijual, biaya tetap, laba pada tingkat penjualan tertentu, rugi pada tingkat penjualan tertentu dan BEP.

\subsubsection{Batas Keamanan (Margin Of Safety)}

Apabila hasil penjualan pada tingkat break even dihubungkan dengan penjualan yang dibudgetkan atau pada tingkat penjualan tertentu, maka akan diperoleh informasi tentang seberapa jauh volume penjualan boleh turun sehingga perusahaan tidak menderita rugi. Hubungan atau selisih antara penjualan yang dibudget atau tingkat penjualan tertentu dengan penjualan pada tingkat break even merupakan tingkat keamanan (margin of safety) bagi perusahaan dalam melakukan penurunan penjualan. Informasi tentang margin of safety ini dapat dinyatakan dalam ratio (prosentase) antara penjualan menurut budget dengan volume penjualan pada tingkat break even, atau dalam prosentase (ratio) dari selisih antara penjualan yang dibugetkan dan penjualan pada tingkat break even dengan penjualan yang dibudgetkan itu sendiri, atau dengan rumus:

1. $\frac{\text { Penjualan per budget }}{\text { Penjualan per break even }} \%$ 


\section{2. $\frac{\text { Penjualan per budget - Penjualan perbreak even }}{\text { Penjualan per budget }} \%$ \\ Penjualan per budget}

\subsubsection{Keterbatasan Dan Manfaat Analisis Titik Impas}

Keterbatasan dari analisis titik impas menurut J. Fred Weston et al (1993 : 309) adalah: "Analisis pulang pokok (titik impas) berguna untuk mempelajari hubungan antara volume kegiatan, harga dan biaya, sehingga dapat dipakai dalam penetapan harga, pengendalian biaya dan keputusan tentang program ekspansi. Bagaimanapun juga, sebagai pedoman untuk tindakan manajemen, analisis pulang pokok memiliki beberapa keterbatasan.” Analisis pulang pokok linier terutama lemah dalam hal penggunaan untuk memperkirakan kemungkinan penjualan perusahaan. Analisis pulang pokok juga mengandung kelemahan dalam kaitannya dengan biaya. Jika penjualan meningkat sehingga alat dan mesin bekerja dengan kapasitas penuh, maka diperlukan tambahan tenaga kerja dan pembayaran lembur meningkat. Hal ini mengakibatkan biaya variabel meningkat tajam. Jika diperlukan tambahan alat dan mesin, maka biaya tetap juga akan meningkat. Demikian juga produk yang dijual perusahaan mungkin akan mengalami perubahan kuantitas dan kualitas. Perubahan dalam bauran produk mempengaruhi tingkat dan sudut kemiringan dari fungsi biaya. Analisis pulang pokok berguna sebagai langkah pertama dalam mengembangkan data dasar yang diperlukan untuk penetapan harga dan untuk keputusan bidang keuangan. Akan tetapi analisis yang lebih rinci diperlukan sebelum diambil keputusan akhir.Selain manfaat ini, analisis titik impas juga memiliki manfaat-manfaat menurut Sigit (1990:2) adalah:

1. Sebagai dasar atau landasan dalam merencanakan kegiatan operasional untuk mencapai laba tersebut. Jadi dapat juga digunakan sebagai dasar perencanaan laba atau profit planning.

2. Sebagai dasar atau landasan untuk mengendalikan kegiatan operasi yang sedang berjalan, yaitu sebagai alat untuk menyesuaikan antara realisasi dengan angka dalam perhitungan atau grafik analisa BEP. Jadi dapat digunakan sebagai alat pengendalian atau sebagai alat kontrol bagi manajemen perusahaan.

3. Sebagai bahan pertimbangan dalam mengambil keputusan yang harus dilakukan oleh manajemen. Misalnya seorang manajer yang akan mengambil keputusan mengenai berapa jumlah penjualan yang boleh diturunkan agar perusahaan tidak menderita kerugian, terlebih dahulu harus mengetahui BEP untuk produk tersebut. 


\subsection{KERANGKA PIKIR}

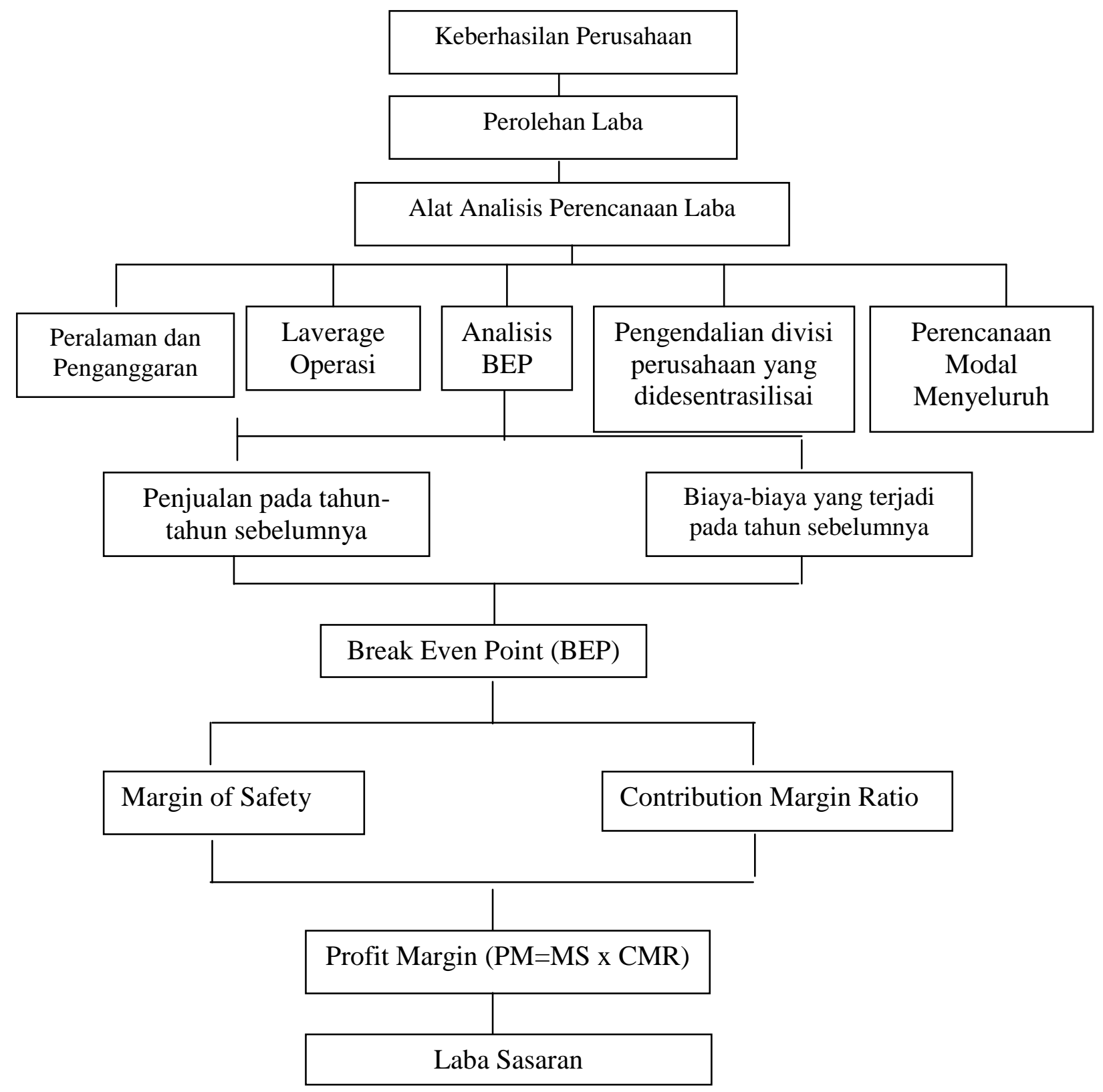

\section{METODOLOGI PENELITIAN}

\subsection{Metode Penelitian}

Penelitian ini menggunakan rancangan penelitian deskriptif - evaluatif, karena di dalam penelitian ini penulis akan menilai laporan rugi-laba pada tahun yang lampau dan mencoba membandingkan dengan perencanaan laba menurut teori.Dasar penelitian ini adalah studi kasus pada salah satu perusahaan yaitu PDAM Tirta Kahuripan Kabupaten Bogor.

\subsection{Variabel Penelitian}

Variabel-variabelnya, terdiri dari Biaya Tetap (fixed cost), Biaya Variabel (variabel cost), Biaya Semi variabel (semi variabel cost), Laba, Contribution Margin Ratio (CMR), Margin of Safety. 


\subsection{Definisi Operasional Variabel}

Variabel-variabel yang penting dalam analisis BEP yang perlu dijelaskan adalah:

a. Biaya Tetap (fixed cost) merupakan biaya yang tidak terpengaruh oleh volume kegiatan dan jumlahnya selalu tetap selama periode tertentu.

b. Biaya Variabel (variabel cost) merupakan biaya yang selalu berubah mengikuti perubahan volume kegiatan.

c. Biaya Semi variabel (semivariabel cost)merupakan biaya yang mengandung sifat tetap sekaligus variabel. Jadi jenis biaya ini terdiri dari biaya tetap dan biaya variabel.

d. Harga Penjualanmerupakan harga yang ditetapkan oleh perusahaan untuk produknya selama periode tertentu.

e. Labamerupakan keuntungan yang diperoleh dari kelebihan harga penjualan atas harga pokok penjualan ditambah biaya-biaya operasi perusahaan.

f. Contribution Margin Ratio (CMR) merupakan ratio antara marginal income dengan hasil penjualannya, sedangkan marginal income adalah selisih antara hasil penjualan dengan biaya variabel.

g. Margin of Safety merupakan hubungan atau selisih antara penjualan yang dibudget atau tingkat penjualan tertentu dengan penjualan pada tingkat break even atau dengan kata lain margin of safety ialah jumlah volume penjualan yang boleh turun, agar perusahaan tidak menderita rugi.

\subsection{Metode Pengumpulan Data}

Untuk melakukan analisis terhadap permasalahan dalam penulisan skripsi ini, penulis mempersiapkan dan mengumpulkan data-data informasi yang sesuai dengan kebutuhan analisis. Adapun langkah-langkah pengumpulan data dalam penelitian ini adalah sebagai berikut :

a. Penelitian kepustakaan untuk menemukan teori-teori yang dijadikan sebagai landasan pelaksanaan penelitian dan diharapkan akan dapat mempermudah penelitian di perusahaan.

b. Riset lapangan, yaitu mendapatkan data dengan jalan mengadakan wawancara dan tanya jawab secara langsung dengan pihak divisi keuangan yang telah memberikan peneliti datadata perusahaan, seperti data penjualan, data-data keuangan yaitu laporan keuangan PDAM Tirta Kahuripan Kabupaten Bogor dari tahun 2011-2015, dan data lainnya yang berhubungan dengan permasalahan yang diteliti. Setelah data-data terkumpul, maka penulis melakukan analisis terhadap laporan keuangan yang telah diperoleh tersebut sehingga diketahui sumber-sumber dan penggunaan dana pada perusahaan dari tahun 2011-2015, kemudian dari data-data tersebut dianalisis perencanaan labanya untuk 2016.

\subsection{Metode Analisis}

Metode analisis yang digunakan dalam penelitian ini adalah sebagai berikut :

a. Pengklasifikasian Biaya

Mengklasifikasikan biaya-biaya yang terjadi pada PDAM Tirta Kahuripan Kabupaten Bogor berupa biaya produksi langsung, biaya produksi tidak langsung, biaya pemasaran dan biaya administrasi dan umum. Kemudian setelah biaya-biaya tadi digolongkan ke dalam biaya tetap, biaya variabel dan biaya semivariabel maka yang termasuk dalam biaya semivariabel dipisahkan lagi menjadi biaya tetap dan biaya variabel dengan menggunakan metode least square.

b. Peramalan penjualan 
Penulis menggunakan data penjualan perusahaan selama 5 (lima) tahun yaitu periode tahun 2011-2015 dan untuk meramalkan penjualan 2016 dengan menggunakan metode least square.

c. Analisis kuantitatif untuk menentukan tingkat BEP, Contribution Margin Ratio (CMR), Margin of Safety, dan marjin laba pada 2011serta proyeksinya untuk 2012.

$$
\begin{array}{ll}
\text { BEP } & =\frac{\text { Total Biaya Tetap }}{1-\frac{\text { Total biaya var iabel }}{\text { Total penjualan }}} \\
\text { BEP } & =\frac{\text { BEP }}{\text { Harg a jual perunit }} \\
\text { CMR } & =1-\frac{\text { Biaya Variabel }}{\text { Total penjualan }} \\
\text { MS } \quad= & \frac{\text { Total Penjualan }- \text { Penjualan BEP }}{\text { Total Penjualan }} \times 100 \% \\
\text { Margi Laba }=\text { CMR x } & \text { MS } \\
\text { Laba } & =\text { Margin Laba } x \text { Total Penjualan }
\end{array}
$$

\section{ANALISIS DAN PEMBAHASAN}

Langkah analisis dan pembahasan dalam penelitian ini adalah :

a. Deskripsi dan klasifikasi biaya-biaya yang terjadi pada PDAM Tirta Kahuripan Kabupaten BogorPeramalan penjualan untuk 2016 pada PDAM Tirta Kahuripan Kabupaten Bogor

b. Analisis kuantitatif untuk menentukan tingkat BEP, Margin of Safety, Contribution Margin, labarugi 2015pada PDAM Tirta Kahuripan Kabupaten Bogor

Analisis Titik Impas sebagai alat perencanaan laba pada 2016.

\subsection{Deskripsian dan Klasifikasi}

Untuk dapat menentukan titik break even, maka biaya yang terjadi harus dapat dipisahkan menjadi biaya tetap dan biaya variabel. Biaya tetap adalah biaya yang jumlah totalnya tetap/tidak berubah dalam range/output tertentu. Sedangkan biaya variabel adalah biaya yang jumlah totalnya akan naik turun sebanding dengan hasil produksi atau volume kegiatan. Dan untuk jenis biaya semivariabel atau semi tetap dalam analisis titik impas perlu dipisahkan terlebih dahulu menjadi biaya tetap dan biaya variabel dengan menggunakan metode-metode tertentu. Berdasarkan hasil penelitian, diketahui bahwa PDAM Tirta Kahuripan Kabupaten Bogor belum mengelompokkan biaya-biaya kedalam biaya variabel dan biaya tetap. Perusahaan hanya mengelompokkan dalam biaya langsung usaha, biaya tidak langsung, dan biaya di luar usaha untuk keperluan penyusunan laporan laba/rugi perusahaan. Maka penulis akan mengelompokkan biaya-biaya tersebut ke dalam biaya tetap dan biaya variabel untuk keperluan perhitungan analisis titik impas yang selanjutnya membuat perencanaan laba pada PDAM Tirta Kahuripan Kabupaten Bogor. Pendeskripsian dan pengklasifikasian biaya yang terjadi pada PDAM Tirta Kahuripan Kabupaten Bogor pada 2015akan digunakan sebagai dasar dalam menentukan besarnya biaya yang akan dikeluarkan perusahaan untuk 2016. Berikut ini adalah daftar biaya-biaya yang dikeluarkan PDAM Tirta Kahuripan Kabupaten Bogor pada 2015yang akan dikelompokkan dalam biaya tetap, variabel dan biaya semivariabel: 
Tabel 4.1.

\begin{tabular}{|c|c|c|c|}
\hline \multirow{2}{*}{ Jenis Biaya } & \multicolumn{3}{|c|}{ Pengelompokan Biaya (Rp) } \\
\hline & Biaya Tetap & Biaya Variabel & Biaya Semivariabel \\
\hline \multirow{2}{*}{\multicolumn{4}{|c|}{ Biaya Langs ung Us aha }} \\
\hline & & & \\
\hline 1. Biaya listrik PLN & & $4,756,599,900$ & \\
\hline 2. Biaya pegawai & & $2,359,604,352$ & \\
\hline 3. Biaya penyusutan instalasi & $1,437,395,169$ & & \\
\hline 4. Biaya air baku & & $1,008,211,320$ & \\
\hline 5. Biaya pemeliharaan & & & $599,788,890$ \\
\hline 6. Biaya bahan kimia & & $549,963,221$ & \\
\hline 7. Biaya bahan bakar dan pehumas & & $191,123,365$ & \\
\hline 8. Biaya bahan pembantu & & $380,682,450$ & \\
\hline 9. Rupa-rupa biaya operasional & & $2,362,904$ & \\
\hline \multicolumn{4}{|l|}{ Biaya Instalasi Pengolahan : } \\
\hline 1. Biaya pegawai & & $6,553,262,454$ & \\
\hline 2. Biaya listrik PLN & & $8,152,950$ & \\
\hline 3. Biaya penyusutan instalasi & $3,743,857,334$ & & \\
\hline 4. Biaya bahan kimia & & $3,893,494,734$ & \\
\hline 5. Biaya pemeliharaan & & & $779,442,593$ \\
\hline 6. Biaya bahan bakar dan pehumas & & $582,832,681$ & \\
\hline 7. Biaya bahan pembantu & & $136,003,280$ & \\
\hline 8. Biaya rapat dan tamu & & & \\
\hline 9. Rupa-rupa biaya pengolahan & & $132,331,710$ & \\
\hline 10. Biaya ATK dan cetakan & & & $6,491,245$ \\
\hline \multicolumn{4}{|l|}{ Biaya Transmisi Dan Distribusi : } \\
\hline 1. Biaya Penyusutan insta lasi & $11,424,615,066$ & & \\
\hline 2. Biaya pegawai & & $6,080,951,740$ & \\
\hline 3. Biaya pemeliharaan & & & $3,634,060,759$ \\
\hline 4. Biaya listrik PLN & & $9,209,011,320$ & \\
\hline 5. Rupa-rupa biaya transmisi dan distribusi & & $454,867,944$ & \\
\hline 6. Biaya perlengkapan/pembantu & & $108,106,393$ & \\
\hline 7. Biaya bahan bakar dan pelumas & & $71,432,025$ & \\
\hline 8. Biaya rapat dan tamu & & & $1,678,162$ \\
\hline 9. Biaya persil & & & \\
\hline 10. Biaya ATK dan percetakan & & & $86,709,300$ \\
\hline \multirow{2}{*}{\multicolumn{4}{|c|}{$\begin{array}{l}\text { Biaya Tidak Langs ung } \\
\text { Biaya Umum dan Administrasi : }\end{array}$}} \\
\hline & & & \\
\hline 1. Biaya pegawai administrasi & $27,363,402,985$ & & \\
\hline 2. Biaya kantor & $2,718,794,110$ & & \\
\hline 3. Biaya keuangan & $6,709,194,825$ & & \\
\hline 4. Rupa-rupa biaya umum & & & $1,810,223,325$ \\
\hline 5. Biaya pemeliharaan & & & $877,260,374$ \\
\hline 6. Biaya jasa profesional & $702,867,241$ & & \\
\hline 7. Biaya badan pengawas & $846,831,029$ & & \\
\hline 8. Biaya penelitian dan pengembangan & & & $920,732,957$ \\
\hline 9. Biaya perjalanan dinas & & & $203,020,000$ \\
\hline 10. Biaya sewa & $309,776,828$ & & \\
\hline 11. Biaya retribusi dan pajak perijiman & & & $366,419,094$ \\
\hline 12. Biaya iuran & $125,505,220$ & & \\
\hline 13. Biaya asuransi kesehatan & $1,166,079,825$ & & \\
\hline 14. Biaya keamanan & $38,915,632$ & & \\
\hline 15. Biaya penyusutan & $2,766,336,754$ & & \\
\hline 16. Biaya asuransi kendaraan & $86,600,822$ & & \\
\hline 17. Biaya penyisihan piutang usaha & & $242,457,916$ & \\
\hline 18. Biaya amortisasi & & & \\
\hline Biaya Hubungan Pelanggan : & & & \\
\hline 1. Biaya hubungan pelanggan & & $1,471,014,648$ & \\
\hline JUMLAH & $59,440,172,840$ & $38,192,467,307$ & $9,285,826,699$ \\
\hline
\end{tabular}

Dari pemisahan biaya-biaya yang terjadi pada PDAM Tirta Kahuripan Kabupaten Bogor kedalam biaya tetap, biaya variabel, dan biaya semivariabel, diperoleh bahwa biaya tetap sebesar Rp. 58.146.172.840,- dan biaya variabel sebesar Rp. 81.001.867.307,- serta biaya semivariabel sebesar Rp. 9.285.826.699,-. Biaya semivariabel dipisahkan lagi menjadi biaya tetap dan biaya variabel yang perlu untuk merencanakan, menganalisis, mengendalikan, mengukur, atau mengevaluasi biaya dalam berbagai kegiatan. Dalam analisis titik impas hanya terdapat 2 (dua) biaya yaitu biaya tetap dan biaya variabel, maka biaya semivariabel harus dipisahkan lagi. Penentuan unsur tetap dan variabel dari biaya semivariabel pada PDAM Tirta Kahuripan Kabupaten Bogor dilakukan dengan menggunakan metode least square. Untuk keperluan perhitungan di atas maka perlu diketahui penjualan perbulan selama tahun 2015, sebagai berikut: 
Tabel 4.2.

Daftar Penjualan Perbulan Tahun 2015

\begin{tabular}{|l|l|l|l|}
\hline No & Bulan & $\begin{array}{l}\text { Penjualan Air \& Jasa Administrasi } \\
(\mathrm{Rp})\end{array}$ & $\begin{array}{l}\text { Biaya } \\
\text { Semivariabel }\end{array}$ \\
\hline \hline 1 & Januari & $9,537,476,950$ & $750,975,200$ \\
\hline \hline 2 & Pebruari & $9,495,475,800$ & $793,150,500$ \\
\hline \hline 3 & Maret & $9,514,025,300$ & $745,525,000$ \\
\hline \hline 4 & April & $9,550,475,950$ & $780,350,500$ \\
\hline \hline 5 & Mei & $9,512,476,950$ & $791,525,500$ \\
\hline \hline 6 & Juni & $9,498,450,700$ & $750,125,500$ \\
\hline \hline 7 & Juli & $9,495,345,150$ & $785,250,000$ \\
\hline \hline 8 & Agustus & $9,515,500,250$ & $775,250,000$ \\
\hline \hline 9 & September & $9,495,217,500$ & $750,157,500$ \\
\hline \hline 10 & Oktober & $9,540,285,150$ & $815,005,000$ \\
\hline \hline 11 & Nopember & $9,515,250,200$ & $755,175,500$ \\
\hline \hline 12 & Desember & $9,563,743,338$ & $793,336,499$ \\
\hline \hline Jumlah & $\mathbf{1 1 4 , 2 3 3 , 7 2 3 , 2 3 8}$ & $\mathbf{9 , 2 8 5 , 8 2 6 , 6 9 9}$ \\
\hline
\end{tabular}

Berikut ini penulis menyajikan pemisahan biaya semivariabel dengan menggunakan metode least square sebagai berikut :

Tabel 4.3

Tabel Pemisahan Biaya Semivariabel (Metode Least Square)

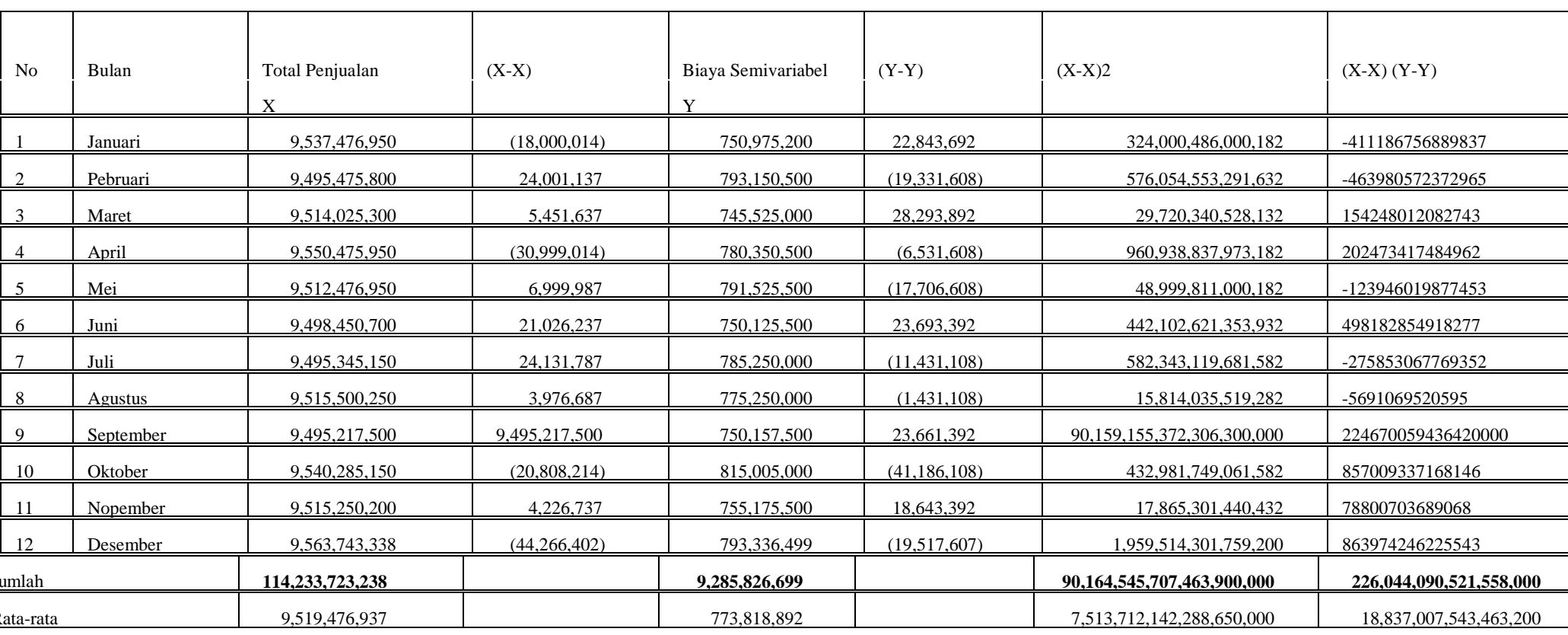

$\mathrm{b}=\frac{\Sigma\left(\mathrm{X}_{\mathrm{i}}-\mathrm{X}\right)\left(\mathrm{Y}_{\mathrm{i}}-\mathrm{Y}\right)}{\Sigma\left(\mathrm{X}_{\mathrm{i}}-\mathrm{X}\right)^{2}}$ 


$$
=\frac{226 \cdot 044 \cdot 090 \cdot 521 \cdot 558 \cdot 000}{90.164 \cdot 545 \cdot 707.463 .900 .000}
$$

$=0,0025$

$=\mathrm{a}+\mathrm{bx}$

$=\mathrm{y}-\mathrm{bx}$

$=9,285,826,699-0,0025(114,233,723,238)$

$=\mathbf{9 , 2 8 5 , 8 2 6 , 6 9 9}-\mathbf{2 8 6}, 385,939$

$=\mathbf{8 , 9 9 9 , 4 4 0 , 7 6 0}$

Total biaya tetap

Rp. $8,999,440,760$

Biaya variabel setiap rupiah penjualan $\quad$ Rp. 0,0025

Total biaya variabel = Rp. 0,0025 x Rp. 114,233,723,238

= Rp. 286,385,939,-

Total biaya tetap dan biaya variabel dalam perusahaan setelah digabungkan dengan pemisahan biaya semivariabel menjadi biaya tetap dan biaya variabel adalah:

Biaya Tetap

Biaya Tetap

Unsur biaya tetap dari biaya semivariabel

Total biaya tetap

Rp. 59,440,172,840,-

Rp. $8,999,440,760,-$

Rp. 68,439,613,600,-

Biaya Variabel

Biaya Variabel

Rp. 38,192,467,307,-

Unsur biaya variabel dari biaya semivariabel

Total biaya variabel

Rp. $286,385,939,-^{+}$

Rp.38,478,853,246,-

\subsection{Peramalan Penjualan}

Dalam menetapkan sasaran laba tertentu, salah satu faktor penting yang harus diperhitungkan ialah besarnya volume penjualan, apabila perusahaan ingin mendapatkan laba atau menderita kerugian. Dalam analisis titik impas, diasumsikan jumlah penjualan adalah sama dengan jumlah produksi, sehingga meramalkan penjualan untuk tahun yang akan datang akan dapat direncanakan beberapa laba yang akan diperoleh perusahaan untuk tahun yang akan datang.Untuk keperluan perhitungan perencanaan laba pada PDAM Tirta Kahuripan Kabupaten Bogor maka penulis mengambil data penjualan perusahaan selama 5 (lima) tahun terakhir yaitu tahun 2011-2015 untuk meramalkan jumlah unit penjualan pada 2016 dengan menggunakan metode least square. Data Penjualan Tahun 2011-2015 PDAM Kahuripan Kabupaten Bogor

\begin{tabular}{|l|l|l|l|l|l|}
\hline No & Tahun & Total Penjualan (Y) & $\mathrm{X}$ & $\mathrm{XY}$ & $\mathrm{X}^{2}$ \\
\hline
\end{tabular}




\begin{tabular}{|c|c|c|c|c|c|}
\hline 1 & 2011 & $68,899,295,769$ & (2) & $(137,798,591,538)$ & 4 \\
\hline 2 & 2012 & $98,386,402,206$ & (1) & $(98,386,402,206)$ & 1 \\
\hline 3 & 2013 & $103,649,999,270$ & - & - & - \\
\hline 4 & 2014 & $108,548,935,169$ & 1 & $108,548,935,169$ & 1 \\
\hline 5 & 2015 & $114,233,723,238$ & 2 & $228,467,446,476$ & 4 \\
\hline \multicolumn{2}{|c|}{ Jumlah } & $493,718,355,652$ & & $100,831,387,901$ & 10 \\
\hline \multicolumn{2}{|c|}{ Rata-rata } & $98,743,671,130$ & & $20,166,277,580$ & 2 \\
\hline
\end{tabular}

Y

$=\mathrm{a}+\mathrm{bx}$

$=\frac{\sum \mathrm{y}}{\sum \mathrm{n}}$

$=\frac{493.718 .355 .652}{5}$

$=98.743 .671 .130$

b $\quad=\frac{\sum x y}{\sum x^{2}}$

$=\frac{100.831 .387 .901}{10}$

$=10.083 .138 .790$

$\mathrm{Y}=\mathrm{a}+\mathrm{bx}$

$=98.743 .671 .130+10.083 .138 .790(3)$

$=98.743 .671 .130+30.249 .416 .370$

$=128.993 .087 .500$

Berdasarkan perhitungan di atas, pendapatan penjualan air PDAM Tirta Kahuripan Kabupaten Bogor untuk 2016 diperkirakan sebesar Rp. 128.993.087.500,-.

\subsection{Analisis Kuantitatif untuk Menentukan BEP, MS, CMR dan LabaRugi 2016 pada PDAM Tirta Kahuripan Kabupaten Bogor.}

Pada sub bagian ini, pertama-tama penulis akan membahas perhitungan brak even point (titik impas). Dalam perhitungan BEP ada beberapa data yang harus ada adalah jumlah total biaya tetap, biaya variabel perunit atau total dan hasil penjualan total atau harga jual perunit. Berdasarkan data-data yang diperoleh dari PDAM Tirta Kahuripan Kabupaten Bogor maka dapat dihitung titik impas total yang sekaligus merupakan titik impas produk PDAM Tirta Kahuripan Kabupaten Bogorsebagai berikut :

$$
\begin{array}{r}
\text { BEP }=\frac{\text { Total Biaya Tetap }}{1-\frac{\text { Total biaya variabel }}{\text { Total penjualan }}} \\
=\frac{68.439 .613 .600}{1-\frac{38.478 .853 .246}{114.233 .723 .238}}
\end{array}
$$




$$
\begin{gathered}
=\frac{68.439 .613 .600}{1-0,33684} \\
=\frac{68.439 .613 .600}{0,66316} \\
=\text { Rp. 103.202.264.310,- }
\end{gathered}
$$

Hasil perhitungan yang diperoleh menunjukkan bahwa PDAM Tirta Kahuripan Kabupaten Bogor telah mencapai tingkat break event point (titik impas) bahkan tingkat penjualan perusahaan untuk 2015sebesar Rp. 114.233.723.238,-telah melampaui tingkat break event point (BEP) yaitu Rp. 103.202.264.310,-. Hal ini menunjukkan bahwa perusahaan memperoleh laba dan besarnya laba yang diperolah PDAM Tirta Kahuripan Kabupaten Bogor untuk 2015dapat diketahui yaitu:
Laba
$=$ Margin Laba $\mathrm{x}$ Total Penjualan
Margi Laba
$=$ Contribution Margin x Margin of Safety

Untuk menghitung margin laba, harus diketahui terlebih dahulu besarnya contribution margin dan margin of safety, maka berikut ini akan dihitung besarnya margin laba, contribution margin, margin of safety dan laba/rugi akan dihitung sebagai berikut :

$$
\begin{aligned}
& \text { CMR = } 1-\frac{\text { Biaya Variabel }}{\text { Total penjualan }} \\
&=1-\frac{R p \cdot 38,478,853,246}{R p \cdot 114,233,723,238} \\
&=1-0,33684 \\
&=0,66316 \\
&=66,316 \%
\end{aligned}
$$

Contribution margin ratio sebesar 66,316\% merupakan ratio antara margin dengan hasil penjualan dan hal ini memberikan informasi bahwa 66,316\% dari penjualan tersedia untuk menutup biaya tetap dan laba.

$$
\begin{aligned}
\text { MS }=\frac{\text { Total Penjualan }- \text { Penjualan BEP }}{\text { Total Penjualan }} \times 100 \% \\
=\frac{\text { Rp. } 114,233,723,238-R p \cdot 103,202,264,310}{R p \cdot 114,233,723,238} \times 100 \% \\
=9,657 \%
\end{aligned}
$$

Margin of safety sebesar 9,657\% berarti tingkat penjualan untuk perusahaan tersebut tidak boleh turun lebih dari 9,657\% dari penjualan yang direncanakan yaitu sebesar:

$=9,657 \%$ x Rp. 114.233 .723 .238

$=$ Rp. 11.031.550.653

Analisis Break Margin Laba $=$ CMR $\times$ MS

$$
\begin{aligned}
& =66,316 \% \text { x 9,657\% } \\
& =6,40 \%
\end{aligned}
$$

Margin laba sebesar 6,40\% artinya apabila perusahaan dapat menjual air atau hasil produksinya sesuai dengan yang dibudgetkan, maka laba yang akan diperoleh sebesar 6,40\% dari hasil penjualan tersebut.

$$
\begin{aligned}
& \text { Laba = Margin Laba x Total Penjualan } \\
& \quad \text { = 6,40\% x Rp. 114,233,723,238,- } \\
& \text { = Rp. 731.118.287,232,-- }
\end{aligned}
$$


Berdasarkan analisis titik impas diperoleh bahwa besarnya laba PDAM Tirta Kahuripan Kabupaten Bogordari hasil penjualan air untuk 2015 adalah sebesar Rp. 731.118.287,232,-

\subsection{BEP sebagai Alat Perencanaan Laba pada 2016}

Pada sub bab sebelumnya, dengan analisis titik impas diketahui bahwa PDAM Tirta Kahuripan Kabupaten Bogor memperoleh laba sebesar Rp. 731.118.287,232,- dan diperkiraan penjualan air akan meningkat pada 2015 sehingga akan berpengaruh pada tingka labanya. Hal ini akan dibuktikan dengan perhitungan analisis titik impas untuk memperkirakan laba perusahaan dari penjualan air pada 2016. Ada beberapa kebijaksanaan dari perusahaan yang akan menyebabkan perhitungan break event point untuk 2016 tidak sama dengan real laba 2016 dan kebijaksanaan perusahaan tersebut adalah sebagai berikut :

1. Perubahan pendapatan penjualan yaitu perusahaan memperkirakan terjadi peningkatan penjualan air untuk 2016

2. Harga Jual diperkirakan akan mengalami kenaikan pada 2016. Hal ini dimaksudkan untuk mengantisipasi kenaikan yang terjadi pada harga bahan baku serta untuk pengeluaran biayabiaya yang lain.

3. Biaya Produksi Langsung diperkirakan akan meningkat proporsional dengan tingkat penjualan pada 2016. Untuk mempermudah pengklasifikasian, maka biaya produksi langsung digolongkan kedalam biaya variabel.

Sedangkan pengeluaran untuk biaya produksi tidak langsung (biaya tetap) untuk 2016 dianggap tidak mengalami perubahan dari tahun sebelumnya.Untuk meramalkan besarnya penjualan pada 2016, penulis menggunakan data penjualan selama 5 tahun terakhir. Pada sub bab sebelumnya dengan menggunakan metode least square untuk peramalan penjualan, diperoleh peramalan penjualan perusahaan pada 2016 adalah sebesar Rp. 128.993.087.500,-

Jadi persentase peningkatan hasil penjualan untuk tahun 2016 adalah sebagai berikut:

$=\frac{(R p \cdot 128 \cdot 993 \cdot 087 \cdot 500-R p \cdot 114 \cdot 233 \cdot 723 \cdot 238)}{R p \cdot 114 \cdot 233 \cdot 723 \cdot 238} \times 100 \%$

$=12,92 \%$

Jadi besarnya kenaikkan penjualan air pada 2016adalah 12,92\% dan proporsional dengan kenaikan biaya variabel. Maka besarnya biaya variabel adalah :

Total Biaya Variabel = Total Biaya Variabel $2011+$ Total kenaikan biaya variabel

$$
\begin{aligned}
& =\text { Rp. 38.478.853.246 + (12,92\%) Rp.38.478.853.246 } \\
& =\text { Rp. 43.450.321.085 }
\end{aligned}
$$

Setelah menentukan besarnya total penjualan dan total biaya variabel untuk 2016, maka penulis akan menentukan BEP, Contribution Margin Ratio, dan Margin of Safety untuk perencanaan laba 2016.

$$
\begin{aligned}
\text { BEP }= & \frac{\text { Total Biaya Tetap }}{1-\frac{\text { Total biaya variabel }}{\text { Total penjualan }}} \\
= & \frac{68.439 .613 .600}{1-\frac{43.450 .321 .085}{128.993 .087 .500}} \\
& =\frac{68.439 .613 .600}{1-0,33684} \\
& =\frac{68.439 .613 .600}{0,66316}
\end{aligned}
$$


Perhitungan titik impas di atas, menunjukkan bahwa selama 2016 perusahaan telah mencapai titik break event total. Bahkan jumlah penjualan total telah melampaui titik break eventnya. Untuk mengetahui besarnya laba pada 2016 dapat dihitung sebagai berikut :

$$
\begin{aligned}
\text { CMR }=1-\frac{\text { Biaya Variabel }}{\text { Total penjualan }} \\
\quad=1-\frac{R p \cdot 43 \cdot 450 \cdot 321 \cdot 085}{R p \cdot 128 \cdot 993 \cdot 087.500} \\
=0,66316 \\
=66,316 \%
\end{aligned}
$$

Contribution margin ratio sebesar 66,316\% merupakan ratio antara margin dengan hasil penjualan yang memberikan informasi bahwa 66,316\% dari penjualan tersedia untuk menutup biaya tetap dan laba.

$$
\begin{aligned}
\text { MS }=\frac{\text { Total Penjualan }- \text { Penjualan BEP }}{\text { Total Penjualan }} \times 100 \% \\
=\frac{\text { Rp. } 128.993 .087 .500-R p .103,202,264,310}{R p \cdot 128.993 .087 .500} \times 100 \% \\
=19,994 \%
\end{aligned}
$$

Margin of safety sebesar 19,994\% berarti tingkat penjualan untuk perusahaan tersebut tidak boleh turun lebih dari 19,994\% dari penjualan yang direncanakan yaitu sebesar :

$=19,994 \%$ x Rp. 128.993 .087 .500

= Rp. 25.790.877.915,-

Apabila tingkat penjualan turun dari 19,994\% maka perusahaan akan mengalami kerugian.

Margin Laba $=$ CMR x MS

$$
\begin{aligned}
& =66,316 \times 19,994 \% \\
& =13,259 \%
\end{aligned}
$$

Margin laba sebesar 13,259\% artinya apabila perusahaan dapat menjual air sesuai yang dibudgetkan, maka laba yang akan diperoleh sebesar 13,259\% dari hasil penjualan tersebut.

Laba = Margin Laba $\mathrm{x}$ Total Penjualan

$$
\begin{aligned}
& =13,259 \% \text { x Rp. 128.993.087.500,- } \\
& =\text { Rp. 17.103.193.472,- }
\end{aligned}
$$

Jadi perkiraan laba yang akan diperoleh PDAM Tirta Kahuripan Kabupaten Bobor dari penjualan air pada 2016 adalah Rp. 17.103.193.472,-

\section{SIMPULAN DAN SARAN}

\subsection{Simpulan}

Setelah mengadakan analisis BEP, maka dapat diambil kesimpulan sebagai berikut :

1. Untuk keperluan penerapan analisis BEP maka biaya-biaya tersebut dibagi menjadi biaya tetap dan biaya variabel. Total biaya tetap untuk 2015adalah sebesar Rp.68.439.613.600,- dan total biaya variabel Rp.38.478.853.246,-.Dengan menggunakan metode least square penulis meramalkan penjualan perusahaan 2016 adalah sebesar Rp. 128.993.087.500,--

2. Hasil perhitungan yang diperoleh menunjukkan bahwa PDAM Tirta Kahuripan Kabupaten Bogor telah mencapai tingkat break event point (titik impas) bahkan tingkat penjualan 
perusahaan untuk 2015 sebesar Rp.114.233.723.238,- telah melampaui tingkat break event point (BEP) yaitu Rp.103.202.264.310,-. dan besarnya laba PDAM Tirta Kahuripan Kabupaten Bogordari hasil penjualan air untuk 2015 adalah sebesar Rp. 731.118.287,232,-

3. Dengan menggunakan metode least square untuk peramalan penjualan, diperoleh peramalan penjualan perusahaan pada 2016 adalah sebesar Rp. 128.993.087.500,-persentase peningkatan hasil penjualan untuk 2016 adalah 12,92\%, karena proporsional dengan kenaikan biaya variabel, maka besarnya biaya variabel adalah Rp. 43.450.321.085.

4. Berdasarkan perhitungan BEP, Contribution Margin Ratio, dan Margin of Safety diperoleh perkiraan laba PDAM Tirta Kahuripan Kabupaten Bobor dari penjualan air pada 2016adalah Rp. 17.103.193.472,-

\subsection{Saran}

Berdasarkan analisis yang telah dilakukan, maka penulis memberikan saran-saran sebagai berikut:

1. Perusahaan sebaiknya melakukan perencanaan laba dimasa yang akan datang untuk melengkapi laporan rugi laba yang diperoleh dari laporan akuntansi. Untuk itu disarankan perusahaan untuk mempertimbangkan penggunaan analisis titik impas sebagai alat perencanaan laba untuk tahun masa akan datang, karena dengan analisis titik impas selain memberikan gambaran tentang hubungan antara biaya, volume dan laba juga dapat membantu manajemen dalam memecahkan masalah.

2. Perusahaan sebaiknya mengantisipasi biaya-biaya yang akan terjadi dengan mengendalikan pengeluaran perusahaan, agar biaya-biaya yang dikeluarkan tidak lebih dari pendapatan yang diperoleh sehingga perusahaan tidak mengalami kerugian.

\section{DAFTAR PUSTAKA}

Bambang Riayanto, Dasar-dasar Pembelanjaan Perusahaan,Yayasan Badan Penerit, Yogyakarta, 1994

J. Fred Weston and Eugene F Brigham, Dasar-dasar Manajemen Keauangan Penerbit Erlangga, Jakarta, Edisi 11, 1993

J. Fred Weston and Thomas E. Copeland, Manajemen Keuangan, Binarupa Aksara, Jakarta, Edisi ke 9, 1993

Mulyadi, Akuntansi Biaya Untuk Manajemen, Badan Penerbit Fakultas Ekonomi, Yogyakarta, 1992

S. Munawir, Analisis Laporan Keuangan, Penerbit LIBERTY, Yogyakarta, Edisi ke 5, 1993

Soehardi Sigit, Analisis Break Event, badan Penerbit Fakultas Ekonomi, Yogyakarta Anggota IKAPI, Edisi 3, 1994

Steve H. Karnadi, Manajemen Perusahaan, Yayasan Promotio Humana, Jakarta, 1993

Suad Husnan, Pembelanjaan Perusahaan, Penerit LIBERTY, Yogyakarta, 1992

Syafarudin Alwi, Alat-alat Analisis dalam Pembelanjaan, Penerbit Andi Offset, Yogyakarta, Edisi Revisi, 1994

Usry, Hammer, Matz, Cost Accounting Planning and Control, South - Western Publishing Co, Cincinati, Ohio, Eight Edition, 1992 